\title{
PENERAPAN MODEL PROBLEM BASED LEARNING UNTUK MENINGKATKAN HASIL BELAJAR SISWA PADA TEMA PERISTIWA DALAM KEHIDUPAN DI KELAS V SDN 17 KENDARI
}

\author{
Herfina $^{1)}$, Amiruddin $\mathrm{B}^{1)}$, La Ode Kaimudin ${ }^{1)}$ \\ 1) Jurusan Pendidikan Guru Sekolah Dasar \\ FKIP Universitas Halu Oleo \\ email: herfina077@gmail.com, amiruddin.b@uho.ac.id, laodekaimudint30@gmail.com
}

\begin{abstract}
Abstrak: Penelitian ini bertujuan untuk mengetahui peningkatan hasil belajar siswa pada tema peristiwa dalam kehidupan di kelas V SDN 17 Kendari. Jenis penelitin ini adalah Penelitian Tindakan Kelas (PTK). Subjek dalam penelitian ini adalah guru dan siswa kelas V SD Negeri 17 Kendari, yang terdiri dari guru dan siswa, 20 orang siswa perempuan dan 14 orang siswa laki- laki. Penelitian ini dilakukan sebanyak dua siklus, setiap siklusnya terdiri dari dua kali pertemuan. Data dalam penelitian ini adalah data kuantitatif yaitu data hasil belajar siswa yang diperoleh dari tes hasil belajar siswa dan data kualitatif diperoleh berdasarkan lembar observasi aktivitas mengajar guru dan lembar observasi belajar siswa dalam proses pembelajaran. Hasil penelitian menunjukkan adanya peningkatan hasil belajar siswa dari siklus I ke siklus II, dengan persentase ketuntasan 58,82\% dengan ratarata 69,11 pada siklus I menjadi $88,23 \%$ dengan rata-rata 80,70 pada siklus II, maka dapat disimpulkan bahwa penerapan model pembelajaran Problem Based Learning dapat meningkatkan hasil belajar siswa kelas V SD Negeri 17 Kendari pada tema peristiwa dalam kehidupan.
\end{abstract}

Kata Kunci: model problem based learning; hasil belajar.

\section{APPLICATION OF PROBLEM BASED LEARNING MODELS TO IMPROVE STUDENT LEARNING OUTCOMES IN THE THEMES OF LIFE IN CLASS V SDN 17 KENDARI}

Abstract: This research aims to determine the improvement of student learning outcomes on the theme of Events in Life in class V SDN 17 Kendari. This type of research is Classroom Action Research (CAR). The subjects in this research were teachers and fifth grade students of SD Negeri 17 Kendari, consisting of teachers and students, 20 female students and 14 male students. This research was conducted in two cycles, each cycle consisting of two meetings. The data in this research are quantitative data that is student learning outcomes data obtained from student learning outcomes tests and qualitative data obtained based on teacher teaching activities observation sheets and student learning observation sheets in the learning process. The results showed an increase in student learning outcomes from cycle I to cycle II, with a percentage of completeness $58.82 \%$ with an average of 69.11 in the first cycle to $88.23 \%$ with an average of 80.70 in the second cycle, then it can be concluded that the application of the Problem Based Learning model of learning can improve the learning outcomes of fifth grade students of SD Negeri 17 Kendari on the theme of events in life.

Keywords: problem based learning model; learning outcomes. 


\section{Pendahuluan}

Menurut Depdiknas keberhasilan pendidikan tidak lepas dari proses belajar mengajar, yang di dalamnya meliputi beberapa komponen yang saling terkait, antara lain: guru (pendidik), siswa (peserta didik), materi (bahan), media (alat/sarana), dan metode atau pola penyampaian bahan ajar. Dalam penyelenggaraannya pendidikan di Sekolah Dasar (SD) ditujukan untuk memberikan bekal dasar yang disesuaikan dengan karakteristik usia anak dan kompetensi yang harus dikuasai oleh siswa dalam aspek kognitif, afektif, dan psikomotorik. Strategi memegang peranan penting dalam rangka pelaksanaan pembelajaran yang di dalamnya terdiri dari model, pendekatan dan metode serta teknik pembelajaran, maka dari itu diperlukan kecerdasan dan kemahiran guru dalam memilih dan menggunakan strategi pembelajaran. Guru diberikan kebebasan untuk memanfaatkan berbagai model, pendekatan dan metode pembelajaran yang dapat menumbuhkan minat, keterampilan proses, perhatian, dan keaktifan siswa sehingga proses pembelajaran menjadi lebih bermakna (Rahmasari, 2016, pp. 2-3).

Menurut Trianto Dasar-dasar IPA meliputi empat unsur yaitu: 1) Sikap : rasa ingin tahu mengenai fenomena alam, makhluk hidup, serta hubungan sebab akibat yang menimbulkan masalah baru yang dapat dipecahkan melalui cara-cara yang benar: IPA bersifat open ended. 2) Proses: cara memecahkan masalah melalui metode ilmiah, meliputi penyusunan hipotesis, perencanaan percobaan, evaluasi, pengukuran, dan penarikan kesimpulan. 3) Hasil: berupa kenyataan, patokan atau ukuran, pemikiran dan hukum. 4) Aplikasi: penerapan cara-cara ilmiah dan dasar-dasar IPA dalam kehidupan sehari-hari. Empat unsur tersebut merupakan ciri IPA yang berhubungan antara satu dengan yang lain. IPA menjadi mata pelajaran yang penting karena memberikan pengetahuan dengan lingkungan alam, pengembangan keterampilan, dan cakupan ilmu teknologi dalam kaitannya di lingkungan sekitar. IPA merupakan pembelajaran yang wajib dipelajari oleh siswa SD. Hal ini tercermin dari keikutsertaannya IPA sebagai mata pelajaran yang diujikan dalam ujian nasional tingkat SD (Varia Zuliyaningsih, Elita, 2018, p. 48).

Menurut Wahab Pembelajaran IPA merupakan pembelajaran yang sangat penting karena dapat diterapkan dalam kehidupan sehari-hari dan memuat materi pembelajaran yang sering ditemukan dalam lingkungan peserta didik (Syafriana, 2017, p. 33). Samatowa juga menyatakan bahwa pembelajaran IPA di (SD) hendaknya membuka kesempatan untuk memupuk rasa ingin tahu siswa secara alamiah. Hal tersebut akan membantu siswa dalam mengembangkan kemampuan bertanya, cara berpikir ilmiah, dan mencari jawaban berdasarkan bukti. Fokus pengajaran IPA di SD hendaknya ditujukan untuk memupuk minat dan pengembangan siswa yang sesuai dengan kehidupan siswa itu sendiri (Istanti, 2015, p. 4).

Namun dalam penerapnnya, pembelajaran IPA masih belum sesuai dengan kebutuhan siswa yaitu untuk kemampuan berfikir kritis dan memecahkan masalah yang berpengaruh terhadap hasil belajar. Hal tersebut dapat dibuktikan dengan observasi dan wawancara yang dilakukan oleh peneliti pada tanggal 19 November 2019 dikelas V SDN 17 Kendari, bahwa hasil belajar siswa terkhusus pada materi suhu dan kalor rendah. Salah satu yang menyebabkan hal tersebut karena pembelajaran masih berpusat pada guru, guru kurang dalam hal memberikan ruang kepada siswa untuk berdiskusi dan bekerjasama melalui pembentukan kelompok dalam pembelajaran. Guru cenderung menjelaskan dengan metode ceramah dan memberikan soal kepada siswa setelah pemberian materi. Sehingga siswa merasa jenuh dan bosan dan kurang mengerti penjelasan guru. Hal-hal tersebut berdampak pada hasil belajar siswa yang rendah dan belum mencapai KBM yaitu 75 . Dilihat dari hasil ulangan harian pada materi suhu dan kalor siswa kelas V SDN 17 Kendari, sekitar 20 atau 58\% dari 34 siswa belum memenuhi KBM dengan nilai rata-rata 
65. Berdasarkan hasil tersebut diperlukan model pembelajaran yang bisa memfasilitasi siswa untuk aktif mengembangkan kemampuan berfikir tingkat tinggi yaitu dengan menerapkan model Problem Based Learning untuk meningkatkan hasil belajar siswa.

Menurut Hanafi dan Wahyudi Problem Based Learning (PBL) terdiri dari kegiatan memberikan permasalahan autentik kepada siswa, sehingga menjadikan masalah nyata sebagai dorongan untuk proses belajar sebelum mengetahui konsep formal. Pembelajaran masalah autentik pada siswa dapat melibatkan dalam memecahkan masalah nyata pada kehidupan sehari-hari (Setiyaningrum, 2018, p. 102). Menurut Mustamilah Model Problem Based Learning (PBL) adalah pembelajaran yang memberikan masalah kepada siswa dan siswa diharapkan dapat menyelesaikan masalah yang diberikan dengan pembelajaran yang aktif. Sehingga pembelajaran yang berlangsung guru hanya fasilitator dan siswa aktif dalam pembelajaran (Setiyaningrum, 2018, p. 100).

Menurut Pierce dan Jones dalam penerapan Problem Based Learning (PBL) ada proses yang harus dimunculkan seperti: keterlibatan (engagement), penyelidikan dan investigasi, performance, tanya jawab dan diskusi. Engagement bertujuan untuk mempersiapkan siswa berperan sebagai pemecah masalah (self-directioned problem solver) yang dapat bekerja sama dengan pihak lain, menghadapakn siswa pada situasi yang dapat mendorong untuk dapat menemukan masalah, menyelidiki, dan menyelesaikannya. Kegiatan penyelidikan dan investigasi termasuk mengeksplorasi cara-cara menjelaskan dan implikasi, serta kegiatan mengumpulkan dan mendistribusikan informasi. Performa bertujuan untuk mempresentasikan temuan yang diperoleh. Tanya jawab dan diskusi yaitu menguji ketepatan solusi dan merefleksikan pemecahan masalah yang dilakukan (Rezky, 2016, p. 362).

Berdasarkan dasar-dasar pemikiran dan kenyataan di lapangan yang dikemukakan di atas, peneliti terdorong untuk melakukan suatu Penelitian Tindakan Kelas (PTK) yang berjudul: Penerapan Model Problem Based Learning untuk Meningkatkan Hasil Belajar Siswa pada Tema Peristiwa dalam Kehidupan Dikelas V SDN 17 Kendari. Masalah dalam penelitian ini adalah Bagaimanakah aktivitas mengajar guru dalam proses pembelajaran melalui model Problem Based Learning?, bagaimanakah aktivitas belajar siswa dalam proses belajar melalui model Problem Based Learning?, dan apakah penggunaan model Problem Based Learning dapat meningkatkan hasil belajar siswa pada tema Peristiwa dalam Kehidupan di kelas V SDN 17 Kendari?

\section{Metode Penelitian}

Penelitian ini termasuk dalam jenis penelitian Classroom Action Research (CAR) atau biasa disebut Penelitian Tindakan Kelas (PTK). Penelitian tindakan kelas adalah penelitian ynag dilakukan oleh pendidik dikelasnya melalui refleksi diri. Tujuannya adalah untuk memperbaiki kinerjanya sebagi pendidik, sehingga hasil belajar pesertadidik menjadi meningkat secara sistem, mutu pendidikan pada satuan pendidikan juga meningkat (Tampubolon, 2014, p. 19). Adapaun langkah-langkah penelitian tindakan kelas yaitu perencanaan, pelaksanaa, pengamatan, dan reflleksi (Arikunto, 2015, p. 42). Subjek dalam penelitian ini adalah siswa kelas V SDN 17 Kendari yang terdaftar pada semester genap Tahun Pelajaran 2019/2020. Jumlah siswa sebanyak 34 orang, yang terdiri dari 14 orang laki-laki dan 20 orang perempuan. Faktor yang diteliti dalam penelitian ini adalah sebagai berikut: 1) Faktor siswa meliputi: (a) Aktivitas belajar siswa dalam proses pembelajaran dengan menggunakan model Problem Based Learning (PBL). (b) Kemampuan siswa di dalam memecahkan masalah. 2) Faktor guru yaitu aktivitas mengajar guru dalam proses pembelajaran dengan menggunakan model Problem Based Learning (PBL). 3) Faktor hasil belajar Melihat hasil belajar siswa setelah diterapkan model Problem Based Learning 
(PBL) pada setiap akhir siklus tindakan yang dilakukan oleh guru. Menurut Suparman Problem Based Learning (PBL) adalah suatu model strategi pembelajaran yang peserta didiknya secara kolaboratif memecahkan problem dan merefleksi pengalaman. Melalui model tersebut diharapkan peserta didik lebih aktif dan pembelajaran lebih bermakna dengan pengalaman yang dimiliki (Purnaningsih \& Relmasira, 2019, p. 3). Seperti yang ditegaskan oleh Trianto tujuan PBL membantu peserta didik mengembangkan keterampilan berpikir dan keterampilan mengatasi masalah, belajar peranan orang dewasa yang autentik dan menjadi pembelajaran yang mandiri (Purnaningsih \& Relmasira, 2019, p. 3).

Penelitian ini dilaksanakan pada bulan Februari bertempat di SD Negeri 17 Kendari yang beralamat di Jl. Ir. H. Alala, Kel. Tipulu, Kec. Kendari Barat, Kota Kendari Provinsi Sulawesi Tenggara. Dengan pelaksanaan tindakan direncanakan sebanyak 2 (dua) siklus, jika dua siklus belum berhasil atau belum tercapainya indikator keberhasilan maka penelitian ini tidak dilanjutkan pada siklus berikutnya (siklus 3), serta tiap siklus terdiri atas 2 (dua) kali pertemuan. Data kualitatif dianalisis secara deskriptif kualitatif. Data dimaksudkan untuk melihat proses pelaksanaan pembelajaran yang dilakukan oleh guru ketika menggunakan model Problem Based Learning. Sedangkan data kuantitatif dianalisis secara deskriptif kuantitatif.

\section{Hasil Penelitian}

\section{Pengamatan Aktivitas Mengajar Guru}

Aktivitas mengajar guru selama proses pembelajaran dengan menggunakan model PBL (Problem Based Learning) siklus I dan Siklus II yang dilaksanakan setiap dua kali pertemuan diamati oleh peneliti atau observer. Hasil pengamatan aktivitas mengajar guru disajikan pada Tabel 4.1 berikut.

Tabel 1. Hasil Pengamatan Aktivitas Mengajar Guru Siklus I dan Siklus II

\begin{tabular}{lccccc}
\hline \multirow{2}{*}{ Uraian } & \multicolumn{2}{c}{ Siklus I } & \multicolumn{2}{c}{ Siklus II } \\
\cline { 2 - 6 } Aktivitas mengajar guru & Pertemuan 1 & Pertemuan 2 & Pertemuan1 & Pertemuan 2 \\
\hline Skor perolehan & 37 & 47 & 58 & 61 \\
\hline Skor maksimal & 64 & 64 & 64 & 64 \\
\hline Persentase (\%) & 57,81 & 73,43 & 90,62 & 95,31 \\
\hline Rata-rata & & 65,62 & & 92,96
\end{tabular}

Berdasarkan Tabel 4.1 di atas, terlihat bahwa persentase aktivitas mengajar guru siklus I yang terdiri dari dua kali pertemuan yakni pertemuan pertama sebesar 57,81 dan pertemuan kedua 73,43. Rata-rata dari kedua pertemuan tersebut sebesar 65,62. Kemudian siklus II terdiri dari dua kali pertemuan yakni pertemuan pertama sebesar 90,62 dan pertemuan kedua sebesar 95,31 dengan rata-rata sebesar 92,96. Berdasarkan nilai-nilai tersebut, sehingga dikatakan efektif . Temuan ini didukung oleh penelitian yang dilakukan oleh (Elita Varia Zuliyaningsih : 2018) bahwa penerapan model Problem Based Learning merupakan model pembelajaran yang bertujuan untuk merangsang pemikiraan peserta didik untuk mampu mengembangkan keterampilan berpikir, keterampilan menyelesaikan masalah, keterampilan intelektual. Sehingga dalam pembelajaran berdasarkan masalah siswa dituntut untuk benar-benar berpikir kritis dalam pemecahan masalah yang dilakukan 
melalui kerja sama dengan kelompok dalam memecahkan permasalahan-permasalahan sehingga dapat memperbaiki poses dan hasil belajar siswa. Hal ini sesuai dengan pendapat Ibrahim dan Nur mengemukakan bahwa pembelajaran berbasis masalah merupakan salah satu pendekatan pembelajaran yang digunakan untuk meransang berpikir tingkat tinggi siswa dalam situasi yang berorientasi pada masalah dunia nyata, termasuk didalamnya belajar bagaimana belajar (Nurdin, 2016, p. 222).

\section{Pengamatan Aktivitas Belajar siswa Siklus I dan Siklus II}

Selama proses pembelajaran berlangsung, disamping peneliti atau observer mengamati aktivitas mengajar guru, peneliti juga mengamati aktivitas belajar siswa yang dilaksanakan dalam dua kali pertemuan pada siklus I dan dua kali pertemuan pada siklus II. Hasil pengamatan aktivitas belajar siswa siklus I dan II disajikan pada tabel berikut:

Tabel 2. Hasil Pengamatan Aktivitas Belajar Siswa Siklus I dan Siklus II

\begin{tabular}{|c|c|c|c|c|c|c|c|c|c|c|c|c|c|}
\hline \multirow{3}{*}{ No. } & \multirow{3}{*}{ Uraian } & \multicolumn{12}{|c|}{ Hasil pengamatan siklus I } \\
\hline & & \multicolumn{6}{|c|}{ Pertemuan 1/ Perkelompok } & \multicolumn{6}{|c|}{ Pertemuan 2 / Perkelompok } \\
\hline & & K1 & $\mathrm{K} 2$ & K3 & $\mathrm{K} 4$ & K5 & K6 & K1 & $\mathrm{K} 2$ & K3 & $\mathrm{K} 4$ & K5 & K6 \\
\hline 1. & $\begin{array}{l}\text { Skor } \\
\text { perolehan }\end{array}$ & 33 & 33 & 32 & 31 & 34 & 33 & 40 & 37 & 39 & 38 & 43 & 39 \\
\hline 2. & $\begin{array}{l}\text { Skor } \\
\text { maksimal }\end{array}$ & 48 & 48 & 48 & 48 & 48 & 48 & 48 & 48 & 48 & 48 & 48 & 48 \\
\hline 3. & $\begin{array}{l}\text { Persentase } \\
(\%)\end{array}$ & 68,75 & 68,75 & 66,66 & 64,58 & 70,83 & 68,75 & 83,33 & 77,08 & 81,25 & 79,16 & 89,58 & 81,25 \\
\hline 4. & Rata-rata $(\%)$ & \multicolumn{6}{|c|}{68,05} & \multicolumn{6}{|c|}{81,94} \\
\hline
\end{tabular}

Tabel 3. Hasil Pengamatan Aktivitas Belajar Siswa Siklus II

\begin{tabular}{|c|c|c|c|c|c|c|c|c|c|c|c|c|c|}
\hline \multirow{3}{*}{ No. } & \multirow{3}{*}{ Uraian } & \multicolumn{12}{|c|}{ Hasil pengamatan siklus II } \\
\hline & & \multicolumn{6}{|c|}{ Pertemuan 1/ Perkelompok } & \multicolumn{6}{|c|}{ Pertemuan 1/ Perkelompok } \\
\hline & & K1 & $\mathrm{K} 2$ & K3 & K4 & K5 & K6 & $\mathrm{K} 1$ & $\mathrm{~K} 2$ & K3 & K4 & K5 & K6 \\
\hline 1. & $\begin{array}{l}\text { Skor } \\
\text { perolehan }\end{array}$ & 44 & 44 & 46 & 45 & 44 & 43 & 46 & 47 & 46 & 47 & 46 & 46 \\
\hline 2. & $\begin{array}{l}\text { Skor } \\
\text { maksimal }\end{array}$ & 48 & 48 & 48 & 48 & 48 & 48 & 48 & 48 & 48 & 48 & 48 & 48 \\
\hline 3. & $\begin{array}{l}\text { Persentase } \\
(\%)\end{array}$ & 91,66 & 91,66 & 95,83 & 93,75 & 91,66 & 89,58 & 95,83 & 97,91 & 95,83 & 97,91 & 95,83 & 95,83 \\
\hline 4. & $\begin{array}{l}\text { Rata-rata } \\
(\%)\end{array}$ & \multicolumn{6}{|c|}{277,07} & \multicolumn{6}{|c|}{289,57} \\
\hline
\end{tabular}


Berdasarkan Tabel 2 dan Tabel 3, terlihat bahwa pada aktivitas belajar kelompok siklus I pertemuan 1 adalah kelompok $1=68,75$, kelompok $2=68,75$, kelompok $3=66,66$, kelompok 4=64,58, kelompok 5=70,83 dan kelompok $6=68,75$, dengan rata-rata 68,05. Selanjutnya pada pertemuan 2 persentase aktivitas belajar kelompok adalah kelompok $1=$ 83,33 , kelompok $2=77,08$ kelompok $3=81,25$, kelompok $4=79,16$, kelompok $5=89,58$ dan kelompok $6=81,25$ dengan rata-rata 81,94 . Kemudian pada hasil pengamatan siklus II terlihat bahwa persentase kelompok pada aktivitas belajar kelompok siklus I pertemuan 1 adalah kelompok $1=91,66$, kelompok $2=91,66$, kelompok $3=95,83$, kelompok 4=93,75, kelompok 5=91,66 dan kelompok $6=89,58$ dengan rata-rata 277,07 . Selanjutnya pada pertemuan 2 persentase aktivitas belajar kelompok adalah kelompok $1=95,83$, kelompok $2=97,91$, kelompok $3=95,83$, kelompok $4=97,91$, kelompok $5=95,83$ dan kelompok $6=$ 95,83 dengan rata-rata 289,57.

\section{Hasil Analisis Tes Siklus I dan Siklus II}

Setelah pelaksanaan tindakan siklus I dan II selama 4 kali pertemuan, maka kegiatan selanjutnya adalah evaluasi siklus I dan siklus II. Hal ini dilakukan untuk mengukur sejauh mana kemampuan kognitif siswa setelah guru menerapkan model PBL (Problem Based Learning) dalam proses pembelajaran. Evaluasi dilakukan secara individu, karena dengan cara ini peneliti bisa melihat kemampuan kognitif siswa atas materi yang telah diajarkan. Dalam pencapaian hasil belajar siswa dikelompokkan dalam dua kategori yaitu kategori tuntas dan kategori tidak tuntas.

Untuk lebih jelasnya hasil evaluasi siklus I dan II serta analisis ketuntasan belajar siswa pada siklus I dan II dapat dilihat pada tabel 4.3 berikut:

Table 4. Hasil Analisis Tes Siklus I dan Siklus II

\begin{tabular}{llcc}
\hline No & \multicolumn{1}{c}{ Uraian } & \multicolumn{2}{c}{ Nilai Tes } \\
\cline { 3 - 4 } & & Siklus I & Siklus II \\
\hline 1. & Jumlah & 23,50 & 27,44 \\
\hline 2. & Rata-rata & 69,11 & 80,70 \\
\hline 3. & Persentase ketuntasan & 58,82 & 88,23 \\
\hline 4. & Persentase belum tuntas & 41,17 & 11,77 \\
\hline
\end{tabular}

Setelah mengetahui kekurangan yang terjadi pada siklus I baik itu yang dilakukan oleh guru maupun siswa, maka pada pembelajaran siklus II guru akan mencoba meminimalisir kesalahan-kesalahan yang dilakukan sebelumnya, sehingga hasil belajar dengan menerapkan model Problem Based Learning (PBL). sesuai dengan yang diharapkan yaitu sesuai dengan indikator keberhasilan mencapai $76 \%$. Setelah digunakan model Problem Based Learning (PBL) pada materi pengaruh kalor terhadap perubahan suhu dan wujud benda yang dilaksanakan dalam dua kali pertemuan, kemudian dilaksanakan evaluasi atau tes akhir tindakan siklus II berupa tes tertulisDari tabel analisis tindakan siklus II sebelumnya menunjukkan bahwa penguasaan siswa terhadap materi pelajaran mengalami peningkatan dibandingkan dengan hasil tes siklus I. Pada tes siklus ini, banyaknya siswa yang memperoleh nilai $\leq 75$ sebanyak 4 orang dari 34 siswa atau hanya 11,77 sedangkan yang memperoleh nilai $\geq 75$ sebanyak 30 orang atau 88,23 dengan nilai rata-rata 80,70. Dengan demikian hasil observasi aktivitas siswa dari siklus I ke siklus II mengalami peningkatan yaitu dari kategori cukup ke kategori baik. Hasil observasi atau pengamatan dalam penelitian ini mengalami peningkatan. Secara tersusun persentase ketuntasan hasil setiap siklus pada siklus I maupun Siklus II pada siswa di kelas V SDN 17 Kendari. 


\section{Pembahasan}

\section{Pengamatan Aktivitas Guru}

Proses pembelajaran IPA pada tema peristiwa dalam kehidupan di kelas V SDN 17 Kendari dengan menerapkan model Problem Based Learning (PBL) Pada siklus I ini, aktivitas guru dan siswa cukup baik meskipun dalam kegiatan pembelajaran berlangsung masih ada kekurangan-kekurangan dalam pelaksanaannya. Skor perolehan aktivitas mengajar guru pada siklus I pertemuan I adalah sebesar 57,81\% dengan kategori kurang efektif, sedangkan pada pertemuan II adalah 73,43\% dengan kategori efektif. Hal ini menunjukkan bahwa masih terdapat beberapa kekurangan guru dalam melaksanakan kegiatan pembelajaran, guru belum efektif dalam melakukan tindakan pembelajaran serta tidak efisien dalam penggunaan alokasi waktu pembelajaran.

Hal itu dapat dilihat pada hasil observasi yang dilakukan guru menunjukkan bahwa masih ada beberapa aspek yang belum terlaksana dengan baik dalam proses pembelajaran yang menyebabkan kegiatan pembelajaran belum bersifat aktif dan masih ada siswa yang bermain-main pada saat kegiatan pembelajaran berlangsung. Berdasarkan hasil refleksi siklus I, diperoleh data bahwa ada beberapa kelemahan guru dalam menggunakan model Problem Based Learning (PBL) terkhusus peristiwa dalam kehidupan, yaitu: a) Guru belum mengorganisakan waktu dengan baik sehingga waktu yang digunakan kurang efektif, b) Keaktifan siswa dalam bertanya kepada guru kurang baik, karena masih banyak siswa yang tidak bertanya kepada guru. c) Guru kurang memberikan motivasi kepada siswa, sehingga siswa kurang serius dalam proses pembelajaran.

\section{Pengamatan Aktivitas Siswa}

Berdasarkan hasil pengamatan yang dilakukan oleh peneliti selama kegiatan pembelajaran siklus I dan siklus II dapat disajikan pada gambar berikut ini.

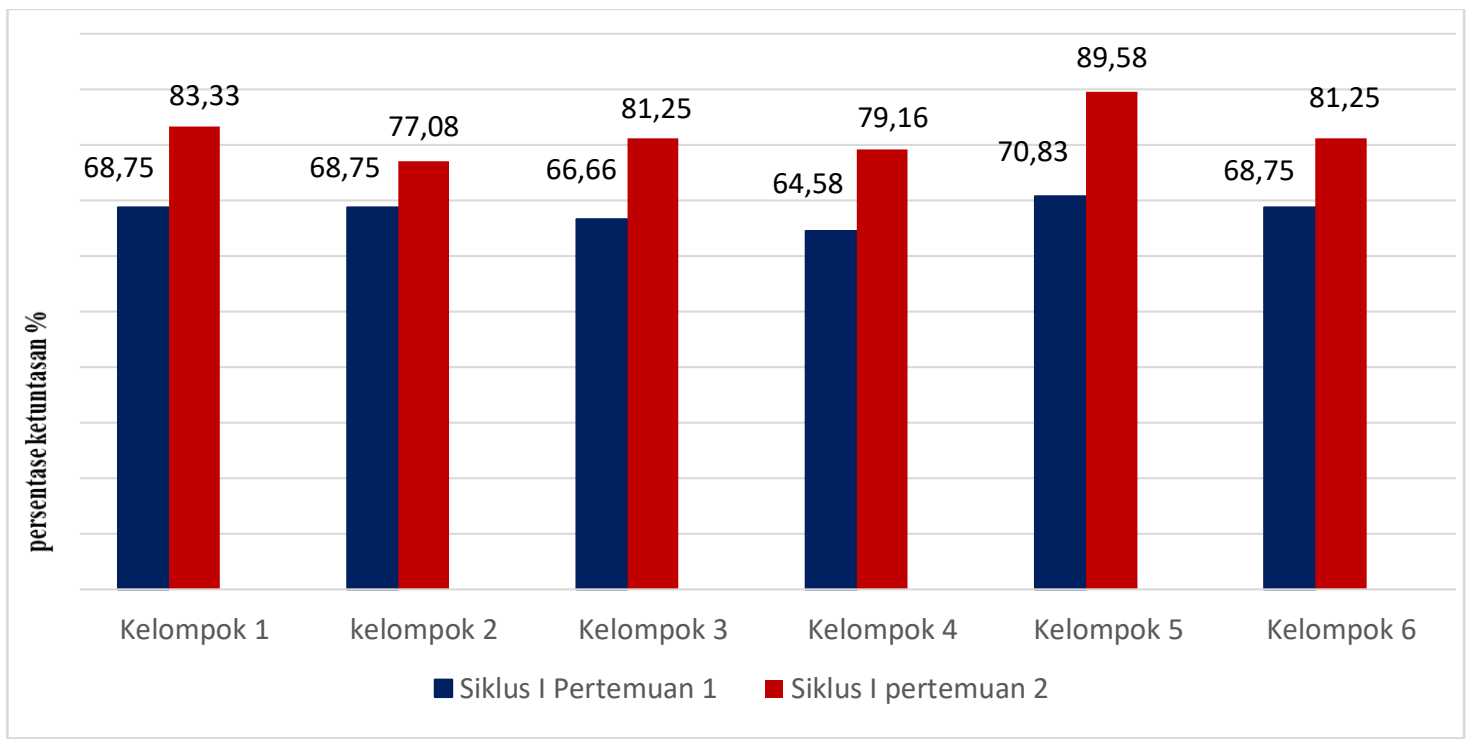

Gambar 1. Hasil Pengamatan Aktivitas Belajar Siswa Siklus I

Penelitian dilanjutkan pada siklus II, karena pada siklus I aktivitas dan nilai diperoleh siswa belum mencapai standar indikator keberhasilan yang ditetapkan yaitu $76 \%$. Perolehan skor rata-rata aktivitas belajar kelompok siswa pada siklus I pertemuan pertama adalah sebesar 68,05 dengan kategori efektif, sedangkan pada pertemuan kedua adalah 81,94. Perolehan nilai siswa pada siklus I secara keseluruhan mencapai persentase 
ketuntasan 58,82\% ketuntasan ini belum mencapai target peneliti yaitu siswa belum mencapai 76\%. Berdasarkan hasil tersebut dilakukan refleksi pada siklus I untuk memberikan alternatif perbaikan pada pembelajaran siklus II, agar aktivitas dan nilai perolehan siswa dapat meningkat dan mencapai standar indikator yang telah ditetapkan. Berdasarkan hal tersebut, maka penelitian dilanjutkan pada siklus II dengan alternatif perbaikan pembelajaran. berikut ini.

Hasil pengamatan aktivitas belajar siswa siklus II dapat disajikan pada gambar

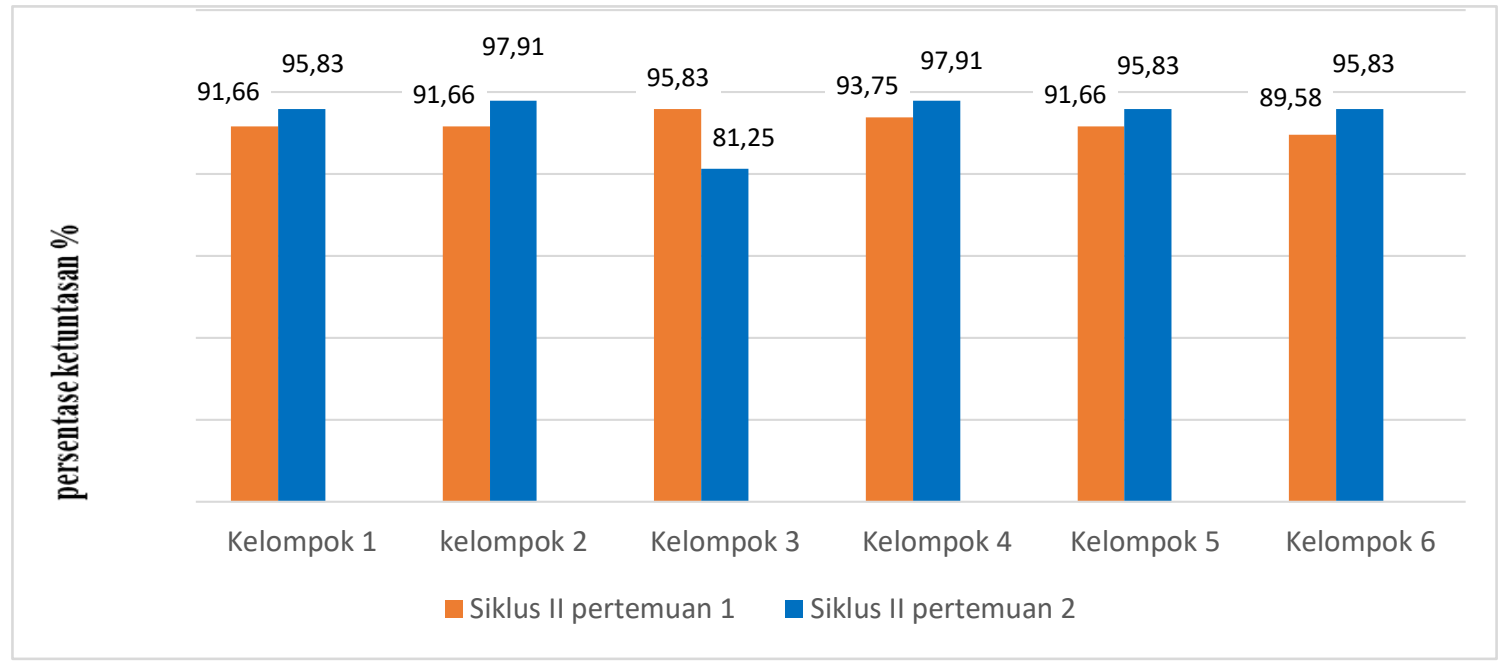

Gambar 2. Hasil Pengamatan Aktivitas Belajar Siswa Siklus II

Peningkatan hasil belajar siswa pada siklus I disebabkan oleh adanya aktivitas siswa dalam memecahkan masalah. Dalam model Problem Based Learning (PBL) ini, peran guru sebagai vasilitator untuk memfasilitasi siswa saat proses pembelajaran dengan mengikuti beberapa tahapan yaitu orientasi siswa pada masalah dimana pada tahap ini, guru harus menjelaskan tujuan pembelajaran dan aktivitas yang akan dilakukan agar peserta didik tahu apa tujuan utama pembelajaran, apa permasalahan yang akan dibahas, bagaimana guru akan mengevaluasi proses pembelajaran. Hal ini untuk memberi motivasi kepada peserta didik. Guru harus bisa memberikan motivasi peserta didik untuk terlibat aktif dalam pemecahan masalah yang dipilih. Kemudian mengorganisasikan peserta didik, pada tahap ini guru membantu peserta didik mendefinisikan dan mengorganisasikan tugas belajar yang berhubungan dengan masalah yang telah diorientasi, misalnya membantu peserta didik membentuk kelompok kecil dan membantu peserta didik membaca masalah yang ditemukan pada tahap sebelumnya. Kemudian membimbing penyelidikan individu dan kelompok, Pada tahap ini, guru mendorong peserta didik untuk mengumpulkan informasi sebanyak-banyaknya, melaksanakan eksperimen, menciptakan dan membagikan ide mereka sendiri untuk mendapatkan penjelasan dan pemecahan masalah. Kemudian mengembangkan dan menyajikan hasil karya, pada tahap ini guru membantu peserta didik dalam menganalisis data yang telah terkumpul pada tahap sebelumnya, sesuaikah data dengan masalah yang telah dirumuskan, kemudian dikelompokkan berdasarkan kategorinya. Peserta didik memberi argumen terhadap jawaban pemecahan masalah. Karya bisa dibuat dalam bentuk laporan. Selanjutnya menganalisis dan mengevaluasi proses pemecahan masalah, pada tahap ini, guru meminta peserta didik untuk merekonstruksi pemikiran dan aktivitas yang telah dilakukan selama proses kegiatan belajarnya. Guru dan 
peserta didik menganalisis dan mengevaluasi terhadap pemecahan masalah yang dipresentasikan setiap kelompok.

Hasil yang diperoleh belum maksimal karena pada tahap membimbing pengalaman individual/kelompok, siswa belum bisa berkerjasama dengan kelompoknya. Kemudian, pada tahap mengembangkan dan menyajikan hasil karya, siswa masih malumalu untuk menyampaikan gagasan atau jawaban yang telah kelompok mereka jawab. Kelemahan inilah yang akan ditingkatkan pada siklus II.

Pada siklus II, proses pembelajaran IPA pada tema peristiwa dalam kehidupan di kelas V dengan menerapkan model Problem Based Learning (PBL) sudah terlaksana dengan efektif dan efisien. Karena siswa sudah mampu bekerjasama dengan kelompoknya dan sudah berani mempresentasikan hasil diskusi kelompok sesuai LKPD yang diberikan.

\section{Hasil Analisis Tes Siklus}

Aktivitas belajar siswa dan mengajar guru telah mencapai standar indikator keberhasilan yang ditetapkan. Pada siklus II pertemuan I perolehan skor aktivitas mengajar guru adalah 90,21\% dengan kategori baik, sedangkan pada pertemuan II diperoleh skor 94,56\%. Hasil ini menunjukkan bahwa guru telah melaksanakan kegiatan pembelajaran dengan efektif dan efisien. Adapun perolehan skor rata-rata aktivitas belajar kelompok siswa pada siklus II pertemuan I adalah sebesar 90,21, sedangkan pada pertemuan II adalah 94,56 dengan kategori sangat baik. Perolehan nilai tes hasil belajar siswa pada siklus II secara klasikal telah mencapai persentase ketuntasan yaitu 88,23\%. Dari hasil tersebut penelitian ini telah dianggap berhasil mencapai tergetnya. Dalam penelitian ini keberhasilan siswa dalam melakukan tes menunjukkan bahwa model Problem Based Learning mampu meningkatkan hasil belajar siswa pada pengaruh kalor terhadap perubahan suhu dan wujud benda. Jumlah peningkatan dari siklus I ke siklus II yaitu sebesar $29,41 \%$ atau sebanyak 9 siswa. Dari hasil observasi atau pengamatan dalam penelitian ini mengalami peningkatan. Secara tersusun persentase ketuntasan hasil setiap siklus pada siklus I maupun Siklus II pada siswa di kelas V SDN 17 Kendari dapat dilihat pada Gambar 4.3 berikut ini:

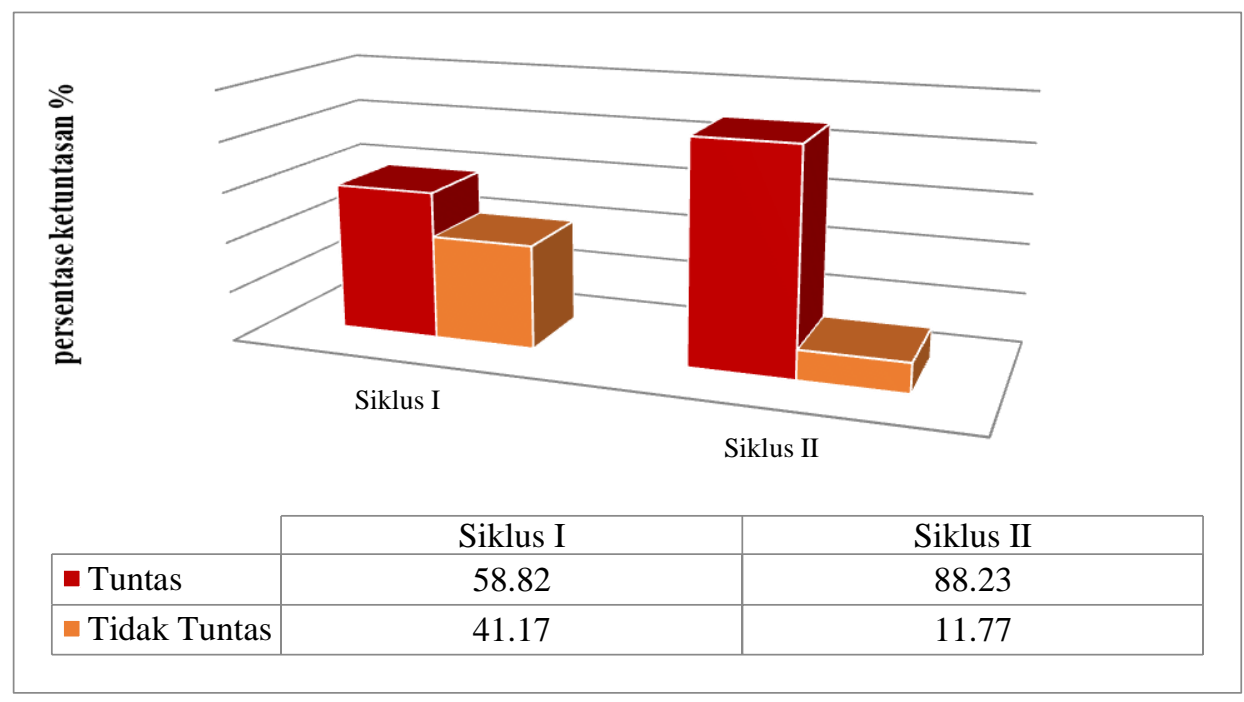

Gambar 3. Diagram Persentase Siswa yang Mengalami Ketuntasan Belajar pada Tes Siklus 
Peningkatan rata-rata aktivitas siswa pada setiap siklus tersebut menandakan bahwa siswa mulai aktif dalam mengikuti pembelajaran. Hasil observasi yang dilakukan peneliti menunjukkan bahwa pelaksanaan pembelajaran dengan penerapan model Problem Based Learning dapat memberikan hasil yang lebih baik walaupun masih terdapat beberapa aktivitas yang tidak mengalami peningkatan yang signifikan, olehnya itu guru harus sering melakukan bimbingan.

Penelitian ini menerapkan model Problem Based Learning pada tema peristiwa dalam kehidupan. Model Problem Based Learning merupakan model pembelajaran yang dalam pelaksanaannya menuntut siswa untuk terlibat aktif selama proses belajar mengajar. Model pembelajaran tersebut dapat membantu siswa untuk mempermudah memahami materi. Sehingga dari uraian tersebut membuktikan bahwa dengan model Problem Based Learning bukan hanya hasil belajar siswa saja yang meningkat melainkan aktivitas mengajar guru dan aktivitas belajar siswa pada tema peristiwa dalam kehidupan di kelas $\mathrm{V}$ SDN 17 Kendari.

Dengan demikian sesuai dengan hipotesis tindakan dalam penelitian ini yaitu jika guru menerapkan model Problem Based Learning hasil belajar siswa pada tema peristiwa dalam kehidupan kelas V SDN 17 Kendari meningkat.

\section{Simpulan}

1. Pengamatan aktivitas mengajar guru dalam proses pembelajaran pada siklus I pertemuan pertama sebesar $57,81 \%$ dan pertemuan kedua sebesar $73,43 \%$ dengan ratarata 65,62. Sedangkan pada siklus II pertemuan pertama sebesar 90,62\% dan pertemuan kedua sebesar 95,31\% dengan rata-rata 92,96.

2. Pengamatan aktivitas belajar kelompok siswa dalam mengikuti proses pembelajaran siklus I pertemuan pertama dengan rata-rata 68,05 dan pertemuan kedua 81,94 sedangkan pada siklus II pertemuan pertama dengan rata-rata 277,77 dan pertemuan kedua 289,57.

3. Penerapan model Problem Based Learning dapat meningkatkan hasil belajar siswa pada tema peristiwa dalam kehidupan di kelas V SDN 17 Kendari, pada siklus I dengan persentase ketuntasan $58,82 \%$ nilai rata-rata 69,11 meningkat pada siklus II mencapai presentase ketuntasan $88,23 \%$ dengan nilai rata-rata 80,70 .

\section{Daftar Pustaka}

Arikunto, suharsimi dkk. (2015). Penelitian Tindakan Kelas (Suryani, Ed.). Jakarta: Bumi Aksara.

Istanti, R. (2015). Pengaruh Model Problem Based Learning Terhadap Motivasi Belajar IPA Siswa Kelas V SDN Gadingan. Jurnal Pendidikan Guru Sekolah Dasar, 2. http://eprints.uny.ac.id/id/eprint/22587

Nurdin, S. dan A. (2016). Kurikulum Dan Pembelajaran. Jakarta: PT RajaGrafindo Persada.

Purnaningsih, W., \& Relmasira, S. C. (2019). Upaya Peningkatan Kemampuan Berpikir Kritis Dan Hasil Belajar Tematik Melalui Model Problem Based Learning (PBL) Kelas V SD. Naturalistic: Jurnal Kajian Penelitan Dan Pendidikan Dan Pembelajaran, 3(2). https://doi.org/10.35568/naturalistic.v3i2.406 
Rahmasari, R. (2016). Penerapan Model Pembelajaran Problem Based Learning untuk Meningkatkan Hasil Belajar IPA Kelas IV SD Application of Problem Based Learning model to increase science learning result of 4th grade student. Jurnal Pendidikan Guru Sekolah Dasar, 36(5), 3456-3465. https://doi.org/10.17509/eh.v5i1.2834

Rezky, M. F. (2016). Effect Of Problem Based Learning ( PBL ) Models Of Critical. 4(7), 361-374. https://doi.org/10.19109/jpmrafa.v6i1.5348

Setiyaningrum, M. (2018). Peningkatan Hasil Belajar Menggunakan Model Problem Based Learning (PBL) pada Siswa Kelas 5 SD. Jurnal Riset Teknologi Dan Inovasi Pendidikan, $1(2)$, 99-108. https://www.neliti.com/publications/266977/peningkatan-hasil-belajarmenggunakan-model-problem-based-learning-pbl-pada-sisw

Syafriana, D. (2017). Penerapan Model Problem Based Learning (PBL) dalam Pendekatan Saintifik untuk Meningkatkan Hasil Belajar IPA kelas V SDN 63 Surabayo. Jurnal Inovasi Pendidikan dan Pembelajaran Sekolah, 1(1), 30-43. https://doi.org/10.24036/02017117932-0-00

Tampubolon, S. (2014). Penelitian Tindakan Kelas Sebagai Pengembangan Profesi Pendidik Dan Keilmuan (S. Saat, Ed.). Ciracas, Jakarta: Erlangga.

Varia Zuliyaningsih, Elita, D. (2018). Penerapan Model Pembelajaran Problem Based Learning (PBL) untuk Peningkatan Hasil Belajar IPA Kelas V Semester II SD

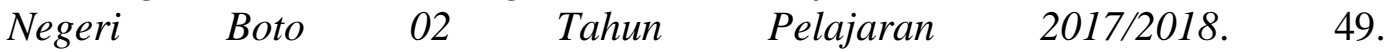
http://dx.doi.org/10.30587/jtiee.v2i1.355 